\title{
Eyes on the Ground and Eyes in the Sky. Satellite and Participatory Surveillance: Photography in Sudan
}

Abstract: The paper analyses the project of participatory surveillance (Ears and Eyes of God, 2009-ongoing) and on the satellite surveillance project (The Satellite Sentinel Project, 2010-2015) in the border area between South and North Sudan. Both projects try to raise awareness of atrocities being committed in this region by various belligerent parties fighting for control over the region and both advocate for the benefit of the civilian communities affected. The paper addresses and analyses the power of photography to deter, advocate, and provide evidence. It analyses the difference between explicit, first-hand visualisation and implied, indicative visualisation of the two projects. It argues that understanding the role of photography in contemporaneity in general (and in these two cases in particular) the investigation should turn away from the questions of re-presentation and focus more closely on the logic of the photographing itself (the act of photography) and its possibility of structuring the reality.

Keywords: satellite surveillance photography, participatory photography, documentary photography, photography of atrocities, Sudan

UDK: 77.044(624)

\footnotetext{
${ }^{1}$ Jan Babnik is a PhD candidate in the Philosophy and Theory of Visual Culture course at the Faculty of Humanities, University of Primorska. He is director of the Membrana Institute. E-mail: jan@membrana.org.
} 


\section{Gledati od blizu in od daleč: satelitska in participatorna fotografija v Sudanu}

Izvleček: Članek analizira projekt participatornega nadzora (Oči in ušesa Boga, 2009- še traja) in projekt satelitskega nadzora (The Satellite Sentinel Project, 2010-2015) na območju meje med Severnim in Južnim Sudanom. Oba projekta se trudita ozaveščati o grozodejstvih, posledicah boja med različnimi frakcijami za prevlado v regiji in oba se zavzemata za skupnosti civilistov, ki jih ta boj najbolj prizadeva. Članek se posveča in analizira moč fotografije za pridobivanje dokazov, zavzemanje za druge in odvračanje od nasilja. Analizira tudi razliko med eksplicitno vizualizacijo iz prve roke in implicitno, indikativno vizualizacijo kot razvidna iz teh dveh projektov. Članek zagovarja tezo, da je za razumevanje vloge fotografije v sodobnosti nasploh (in $\mathrm{v}$ teh dveh primerih še posebej) potrebno usmeriti pozornost stran od vprašanj reprezentacije in se posvetiti bolj logiki samega fotografiranja (fotografskega dejanja) in njegove zmožnosti strukturiranja realnosti.

Ključne besede: satelitsko nadzorna fotografija, participatorna fotografija, dokumentarna fotografija, fotografija grozot, Sudan

$$
\text { *** }
$$

\section{Forensic Paradigm}

In The Crime Scene Photographer by Gail B. Stewart one of the photographers is quoted as saying: "You don't know why you photograph everything - but the detail is the key to crime scene photography."2 The point being that the detail mentioned by the photographer is not the detail that interests the photographer but

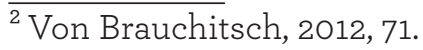


rather the detail that can be revealed, found later on in the investigation process. The imperative is to photograph everything not just the objects of interest but also the empty space - which is "an equivalent motif, a pictorial subject that should be acknowledged as such". ${ }^{3}$ To put it figuratively: to deplete the reality of the scene and transform it into pictorial representation as a whole in view of turning "a temporary scene into a permanent record". ${ }^{4}$ The only way to achieve such an objective ideal of complete record is to act in the manner of the camera, the machine - a crime scene photographer is required to "to switch of thinking and document thoroughly", to be both emotionally and rationally disinterested in their subject matter. To see the world, the object as the ideal omniscient eye of the camera sees it - in its totality, as a complete pictorial entirety from every possible angle.

An example of crime scene photography will be used as a point of reference to discuss notions such as disinterestedness, distance, proximity, involvement and transparency and power in relation to photography's revealing potential. We will more specifically address two projects in Sudan: participatory photography (The Eyes and Ears of God) and satellite surveillance photography (Satellite Sentinel Project). We will analyse these projects through concepts of objective representation and active engagement taken as specific modes of structuring the reality and the events. We will focus on the documentary ideology of visually structuring the world to make possible the emergence of the truth - the incriminating detail.

It is imperative for the crime scene photographer to write down detailed impressions of each photograph (what is to be seen in them

\footnotetext{
${ }^{3}$ Ibid., 73.

${ }^{4}$ Ibid.

${ }^{5}$ Ibid., 71.
} 
what the photographer sees and lastly even what should be seen in them) - all the information which might or might not reveal something later on in the investigative process.

"The crime scene evidence must be accurately documented at the scene by sketch, measurement, photography, and notes for a reconstruction to be attempted. A misallocated item may lead to a wrong interpretation."

Thus creating a multi-layered, multi-sensorial, interdisciplinary "reconstructive image" of the crime scene. A similar process of struggle against photography's reductivism potential was a subject of Geoffrey Batchen's insightful book Forget me not: Photography and Remembrance where he deals with the relationship between memory and the image on the vernacular photo-memorabilia object. He observes "the efforts of ordinary people to overcome - or at least reduce - the power of photography to replace living, emotive memories with static and historical images." These efforts are based on "enriching" the photographs with ornaments - creating memorabilia objects (photographs combined with locks of hair, objects belonging to loved ones, inscriptions, quotations and of course, the titles with the date and location). All this as if in an attempt to "anchor" the photography in words, tactile objects - thus creating complex linguistic-visual-haptic photo-collages or complex "photo-objects" as Batchen terms them. Complex objects that would function as emotive memory triggers - as opposed to pure photographs that provide just factual data or rather more to the point - static, historical, barren, formal facts. Isn't every forensic reconstruction surprisingly similar to such a complex photo-object? Evoking the truth, reconstructing it from past - as is it would a long-

\footnotetext{
${ }^{6}$ Mozayani, Noziglia, 2011, 121.

${ }^{7}$ Batchen, 2004, 94.
} 
lost memory that only contiguity and similarity would resurrect from oblivion. Another way to describe this would be to resort to Roland Barthes and see this as an attempt to tame the "semiotic" madness of photography. In a similar way memorabilia photo-objects are structured with desire to facilitate future memory (future recollection of persons, events) the forensic imagery is based on a model of structuring the visual so as to make possible the "future" emergence of the truth - the incriminating detail - for future incrimination (future use of the images as evidence in the court of law). The truth of the forensic mode is deeply tied to incrimination. And as such it must be transparent - it is imperative to know how it was made, who made it, where, in what context, and how it was perceived by the photographer. This entire context in accordance with the complex production procedures functions as a basis for knowledge - or rather as a model for particular knowledge - for the supposed forensic truth of the event.

In The Burden of Representation John Tagg's view is that what is omitted (i.e. not seen) from this forensic realistic representative system is the process of production itself.

"In realism, the process of production of a signified through the action of a signifying chain is not seen. It is the product that is stressed, and production that is repressed."

But forensic realism does not rest solely on the simplified belief of "eternal, consciousness-independent reality" which is "out there". It rather lies precisely in the belief in the de-subjectification process itself. In the belief that procedures, instruction, careful following of forensic methodology will at the end reveal the reality precisely through the transparency of its procedures. Tagg stresses that in forensic photography there is "an unshaken belief in the photo-

\footnotetext{
$\overline{{ }^{8} \text { Tagg, 1993, } 99 .}$
} 
graph as a direct transcription of the real." But this realism does not lie in the pictorial aspect of photography but rather in its wider social institutional apparatus - in the filing cabinet. There are strict rules that qualify one or the other photograph as being a "direct transcription" of the real - as being a piece of evidence in forensics. There is a difference between the time of "mechanical objectivism" of the middle of the nineteenth century where the burden of representation lay on the image and today where the burden of representation lies in highly evolved interpretive apparatus. ${ }^{10}$

But even in the early days of photography it was never taken for granted because of its likeness to the reality; it was taken for granted because the process was perceived to be completely natural: chemical, optical, and mechanical. Similarity is more or less a cultural "side effect" of a particular era and its particular pictorial conventions. One just needs to take into account non-western traditions of photography to come to the conclusion that photography's naturalism is not to be confused with particular western realism. ${ }^{11}$ To perceive something as being "a copy of" cannot be reduced on perceiving something as "being similar to" in pictorial realistic terms. Photography verism is a specific cultural construct. There is no better example of this notion than the writing of French realism film critic André Bazin in The Ontology of the Photographic Image. Photography "shares, by the virtue of the very process of its becoming, the being of the model of which it is the reproduction; it is the model."12 This is usually termed an indexical nature of photography (that rests on the belief in mechanical reproduction that excludes human agency). What is usually forgotten while quoting

\footnotetext{
${ }^{9}$ Ibid., 98.

${ }^{10}$ See for example: Daston, Galison, 2007.

${ }^{11}$ See for example: Pinney, 2011; Pinney, Peterson, 2003.

12 Bazin, [1948] 2010, 51.
} 
Bazin's "photography as a death mask" syntagm is precisely the social nature of the death mask - the power of which lies in the magic of contact (contagious magic) and is deeply connected to the particular social, cultural uses. One needs to question - when and where does this "law of contact" come into effect - what are the rituals that enforce it? The rituals of the death in the case of that mask. The death mask performs a certain "need" in the ritual of the death. In modern day forensics, the power of photography is measured against its constitutive ritual - the legal system that structures the legally specific "photography realism".

The regime of forensic photography itself it is nothing less than a purely visual regime of exclusion - exclusion of the human factor - the photographer from the picture (in a figurative sense) as an attempt at complete delineation of a photographer's influence (artistry) from the process in such a way that the reality, the event, the crime will "shine through" the process unimpeded. And by that John Tagg's notion of the unshaken belief in the realism of photography reaches its proper meaning. It is not a simplified, naïve belief in photography realism but rather deeply structured (scientific) relation to reality - for the purpose of this article, we are terming it "a forensic paradigm of reality".

The "forensic real" itself as presented in this paradigm is something infinitely reproducible. Walter Benjamin in his The Work of Art in the Age of Mechanical Reproduction states while reflecting on emerging techniques of mass reproduction (photography and film) that there is a strange new "desire of the present-day masses to 'get closer' to things, and their equally passionate concern for overcoming each thing's uniqueness [Oberwindung des Einmaligen jeder Gegebenheit] by assimilating it as a reproduction." ${ }^{\text {"13 }}$ Or to re-




peat from the beginning of our elaboration: to deplete the reality of the scene and transform it into pictorial representation as a whole in view of turning "a temporary scene into a permanent record". But as such forensic realism is far removed from photographic naturalism - the forensic photographer actually works "against" the very nature of photography or at least "nature" as perceived in the tradition of western thought on photography. It tries to minimise its "openness", its strange time-meaning rapture, the effect of what Walter Benjamin termed optical unconsciousness and Roland Barthes, although on slightly different grounds - punctum.

In the book Photographic Evidence: The Preparation and Use of Photography in Civil and Criminal Cases it states:

"[T]here are instances in which counsel must use photographs of amateurish appearance simply because they are the best, or the only, pictures available. Furthermore counsel should avoid obtaining photographs that appear to slickly made or too expensive, lest the jurors come to believe that the presentation is being overdone. Legal photographs should be rich in information but not expansive in appearance" ${ }^{14}$

Amateur photography is admissible in a court of law - it is actually even preferable for the forensic imagery itself to look similar to amateur, vernacular non-artistic images. The forensic paradigm rests on the notion of excluding the modernistic "artistic" authorship of the image, emphasising the realistic artistry of the image making. In addition, realistic artistry encompasses both - the objectified, scientific forensic photography and vernacular, subjective photography. It goes almost without saying that both can be used in a legal model only insofar as the intentions of the photographer

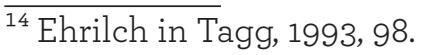


- the author - can be delineated clearly and what remains is deemed a pure document of the reality.

The intentions of the forensic photographer can be rather easily deciphered (since it is based on and strives for uniform, repeatable procedures) whereas it might seem that the intentions of a vernacular photographer are not that easily decipherable. But of course, sometimes the vernacular images are "the only pictures available" and furthermore their mode of production is supposedly quite clear and transparent since the vernacular author is perceived as being basically a naive, quotidian snap-shooter. In his Towards a Philosophy of Photography Vilém Flusser said much the same about a snap-shooter. He merely functions - he is just a functionary in the representative regime. There is a beautiful metaphorical description that Flusser gives us describing the vernacular, quotidian photographer: "Viewing the motion of a man with his camera (or a camera with its man), we are looking at the movements of hunting." 15 The camera of a vernacular photographer is not the extension of the photographer - but rather the opposite holds true - the photographer is an extension of the camera apparatus. What unites the two practices of amateur and forensic would be the syntagm: "Photographing without thinking."

Through the forensic paradigm, the photographer as an operator and the operational side of the images that is revealed - and as such a photography is, in the words of John Tagg "no longer a monument for future memory, but a document for possible use". ${ }^{16}$ The operational aspect of this type of documentary photography needs to be emphasised - in contrast to the misconception of a document as being a factual description (or inscription) of the real, of being a

\footnotetext{
$\overline{{ }^{15} \text { Flusser, 2010, } 37 .}$

${ }^{16}$ Tagg, 1993, 90.
} 
transformation of reality to discursive (written or visual) form, being a mere objective "snapshot" out of an event, process or a state of things - a document has its meaning only in relation to certain use - to certain operation that is to be performed. Therefore, documentary images are operational, performative from the very beginning. Eugene Atget described his works as "documents" in the following context that Molly Nesbit so poignantly explains:

" [...] the photograph was a good document because it could be applied to art as well as to science, providing a 'document vu' to accompany the 'document écrit.' It would tell the truth about, say, a leaf, a doorway, an animal in motion, an earlobe, or an hysteric. So an architectural photograph would be called a document, as would a chronophotograph, a police i.d., or an $\mathrm{X}$ ray. They had one thing in common: all of them were pictures that went to work." (our italics) ${ }^{17}$

\section{Eyes and Ears of God}

The project Ears and Eyes of God (EEG in short) was instigated and started by Slovenian documentary filmmaker, human rights activist, and journalist Tomo Križnar in 2009 in the border region between North and South Sudan where the ongoing conflict between the various belligerent parties and the central Khartoum regime is taking a heavy toll on civilian population. The conflict can be most aptly described as a pre-planned and organised genocide by the Khartoum government against the indigenous communities living in the regions of South Kordofan, Blue Nile and Darfur. In 2009, through the humanitarian foundation H.O.P.E., Tomo Križnar started disseminating small cameras to the affected communities and teaching the volunteers to use the cameras and to upload the

${ }^{17}$ Nesbit in Hutchings, 1997, 237-238. 
images to the world wide web via a satellite connection. The idea behind the project is threefold. The presence of the cameras should function as a deterrent to the perpetrators, the images (created on a large scale by the victims themselves) could be used later on as evidence, and importantly - the online availability of the images themselves should stir the worldwide community into action.

Such an ambitious grass-roots surveillance project is made possible only by advancements in technology and then by the system that enables quick and easy dissemination of images as well as quick production of them. What we are observing is the development of a new kind of "engaged" photography approach - grass roots documentary or its even more engaged, "militant" variant activist participatory photography. Let us observe closely the logic of the project - and how images and the production of imagery are embedded in it. The knowledge of the production of photographs and the means to produce them is passed on to the "participants" of the project. To a lesser extent even the means and knowledge of dissemination (access to distribution channels) is passed on. The emphasis on the role of an author - the photographer, so prevalent in the tradition of documentary, is missing. Importantly, the participants are at the same time the authors of the images and the targeted, selected unprivileged group in focus - in need of help. They produce the images that aim to empower them. This approach is nothing new in the tradition of documentary photography although it was largely repressed by its more canonical, photojournalistic, and art-oriented tradition. Such grass roots, self-representation tradition of documentary can most notably be traced back to the Worker's Film and Photo Leagues of the twenties and thirties of the last century and community photography movement in the seventies. It is a belief that the only real representation of the other is the one that is made by the other - thus enabling self-representation of 
the other - as the only proper way of empowering the unprivileged. But in the EEG project, of course, the purpose is more focused, the images more operational.

It seems that aesthetical mode is absent from the project. How could one even think about the mode of representation, the manner in which the images were made under such horrendous conditions, by the ones exposed to the harshness and atrocities? Nevertheless it is there - it is a mode of vernacular, amateur, snapshot photography. One can hardly imagine aesthetically pleasing, formally perfect imagery to pass as a point-of-fact, down-to-earth reality, presented to us (the global public) through the eyes of real people living through atrocities as they are happening right now. It seems that the aesthetics of press imagery is actually less powerful; the style of press photography (that is readably recognized globally as having a uniform pictorial structure) carries nowadays a strong burden of scepticism. Poignantly - in contemporaneity the objectiveness (the perception of authenticity, realism) can be most effectively achieved through imagery that is distinctly de-subjectified from the point of view of the production - it is almost necessary for the images to be made in such a way as to be recognised as being able to have been made by anybody in order for their indexical value (i.e. representative ambition over the real) to take effect. As an observer one can relate to images if one perceives him or herself as being a possible author of the images. Interestingly there is some new "vernacular realism" at play here - we perceive things to be real only insofar we perceive ourselves as being in the position of an author - and at the same time recognising that it is so precisely because this position is inherently interchangeable - everybody could be an author. The partial aim of the EEG project is to influence (structure) the events themselves by the mere presence of the cameras. The deterrent effect through the perceived om- 
nipresence of the cameras seems to work (at least so it seems for now) even without the sanctions. It is reported by the EEG project that since the presence of the cameras in Darfur sexual assaults on women in the region have gone dramatically down. ${ }^{18}$

The EEG project is all about making the reality visible by providing for incessant photographing and that in turn means completely depleting the reality and transforming it (or should we say) - dissolving it into an image. Making the "ground zero" of horrific events completely transparent. In this we can clearly sense the "forensic" logic of transforming the reality in a pictorial plane - so that the truth, "the incriminating" detail might appear. But there is one important difference - whereas the forensic, crime scene photography structures the closed, secluded, controlled space in a pictorial representation where the truth of the event might appear, the EEG project structures the ongoing actuality, the event itself, for the "pictorial" truth to appear - in order for the truth of the event to disappear. The logic closely follows the logic of a classic, liberal documentary (although as we have seen the EEG project enriches it with the participatory dimension). By making the truth (the horrors, the genocide) visible, thus pictured, the truth should disappear from reality (through a global campaign and by addressing policy makers).

However, EEG tries to structure the reality itself, not just through the process of participatory image making but also through the mere presence of the cameras. The observing subject is missing from this logic; the photography has become instrumentalised. There is almost no need for the visual representation, no need for an observer, for a subjective eye that sees the images. The photography has the ability to structure the reality by its mere

\footnotetext{
${ }^{18}$ Eyes and Ears of God. Available at: http://www.tomokriznar.com/ang/ index.php?li=novice [11.9.2013].
} 
presence - by its very logic, which is deeply imbedded in our conception of reality.

The aim of EEG images is to function as an objective record, a valid testimony; the goal of this project is the future incrimination and at the same time real time deterrence against atrocities. We have seen how the logic of real time deterrence works - but we have neglected the future incrimination aspect. Since most of the images are done by volunteers whose names and identities are not disclosed for obvious reasons, sometimes images lack the interpretative context (the how, who, where, for what purpose ...) which would in a manner quite similar to the forensic one be able to function in the court of law. It is precisely that which gives credibility to these images - the "vernacular realism", the logic of author-lessness of images that could prove problematic in the court of law.

\section{Satellite Sentinel Project}

The Satellite Sentinel Project (SSP in short) was launched on 29 of December as a private and NGO-run satellite surveillance over the border region of South and North Sudan. John Prendergast (co-founder of the Enough Project) and actor George Clooney instigated it. It is hiring DigitalGlobe's satellites to take satellite imagery of the region, provide expert analysis of the images (discerning from the images the threats to civilians, traces of military activities, traces of bombings, grave dig outs etc.), get as much confirmation as possible from the ground and then alert the media, policy makers, the public, and publish the findings. On the first page of their web page, there is a telling description of the project:

"From 300 miles in the sky, the imagery seems indecipherable. But up close, the Satellite Sentinel Project, or SSP, is looking for clues. Researchers on the ground ask questions to try to get 
closer. SSP finds out the facts, and monitors what's really going on in Sudan. Satellite imagery uncovers evidence of alleged atrocities. Stories that alleged war criminals don't want told. Then SSP sounds the alarm. The world is watching because you are watching."19

The images taken from afar by satellite are intended to function as an objective record of events taking place on the ground - war zones. Similar to Eyes and Ears of God, the Satellite Sentinel Project has several objectives:

"What do you get when you combine cutting edge imagery and data analysis? You get a game-changing project that uses technological innovations to document, deter, and seek accountability for war criminals and mass atrocities." ${ }^{20}$

To document, deter, and seek accountability - to paraphrase: to record, to structure the reality on the ground, and to incriminate. Because of the use of the satellite still imagery one has an idea that every image is a crime scene image waiting to be deciphered, explained, clarified - to discern the truth of event from the picture, the event that has already taken place. But there is another side to the project - a pre-emptive side, which is lacking in the EEG project. The aim of the SSP project is also to warn about atrocities before they actually happen - much in the manner of war reconnaissance images - through the assumption of future actions from the tell-tell signs of military activities (building roads, fortification, building artillery positions, moving convoys etc.)

\footnotetext{
${ }^{19}$ The Satellite Sentinel Project. Available at: http://www.satsentinel.org/ [11.9.2013].

${ }^{20} \mathrm{Ibid}$.
} 
"SSP seeks to hold perpetrators of alleged mass atrocities accountable by documenting human rights crimes as they develop and unfold." 21

The role of the author in this project is ultimately reduced to that of the operator of the "machine". The production is perceived as done by the machine - the satellite camera (and an image-making program); images are made from a distance. The truth claim of $S S P$ would be that objectivity is achieved by removing the subjective, human factor from the production - as if the images were produced by themselves. The aesthetics factor is perceived as a burden for the reality of the representation. The indexical value of photography is preserved or valued through distance objectification. The logic of this project falls neatly into the forensic model - or rather into the forensic paradigm.

The truth of the images is hidden in the small granular pixels, in strange pictorial structures in shapes and contours that to the nonprofessional's eye tell nothing. The truth must be revealed through the pointers, diagrams, graphs, cursors, drawn areas, detailed descriptions (a tank, burned house, recently dug out defensive trenches etc ...) even time-lapse imagery (comparison between before and after). It is through the mathematical schemata, through the aesthetics of the objective, the scientific that these images talk to the nonprofessional observer. Not surprisingly, the images lack any emphatic potential, any identification markers with the victims. Between the satellite images and the final recipient there is an interpretative corpus, represented by an expert, one who knows how to interpret the images, one that possess the knowledge of satellite image production - as the general public is perceived as lacking the ability to discern the reality from these images.

${ }^{21}$ Ibid. 
The images of SSP are intended to function as an objective record, a valid testimony; they will "perform" in a court of law in the future - where events will finally be reconstructed in legal, veristic, objective way. Of course - one of the most important goals of SSP is precisely the future incrimination and a real time deterrent effect against atrocities only second. SSP addresses foremost and even specifically the policy makers (as opposed to the EEG project; they have presented their findings to selected senators of the USA Congress). SSP exposes the war machinery, the "invisible" structure of the war happening right now and the war that is about to happen.

\section{Up Close and From Afar}

Even though both projects still rely on the classic, liberal documentary paradigm, they are in contrast with the tradition of classical documentary photography, more or less unorthodox. They both foster a certain reluctance towards the function of the author in a classical sense. Authorship is deemed more or less a burden for the correct representation. In these two projects the author functions more as a facilitator for the production of the images made by the others - in the EEG the participants themselves, in SSP the camera machine the "Cyclops eye" of the satellite. EEG wants to explore every possible viewpoint from every possible angle by as many as possible participants photographers in the field itself - relying on the impact of reality style vernacular photographs taken from close-up in the utmost proximity - in the ground zero of atrocities. The EEG includes a multitude of subjective cameras - achieving objectiveness through the numbers. The SSP relies on the exclusion of the author through distance - through the logic of "viewing from afar", through objective, automated, programmed production of the images.

But there are further developments to the projects. At some level both projects tend to gravitate slowly towards the other in terms of 
their representative regimes. The SSP uses a combination of satellite images and images taken on the ground in a collage manner. And some of the images are actually taken by the participants of $E E G$ project. On the other hand the EEG project has recently started an action of another kind of surveillance - aerial drone reconnaissance - aimed to capture events while they are taking place, from above. Capturing the horrific reality at the very moment of its unfolding, not just recording the aftermath of events, which takes the old photographic logic of "getting closer" to the event to the extreme. Only if we can capture the unfolding of reality at its utmost presence will the international community finally "really see" (as Tomo Križnar so convincingly and emphatically says in the fundraising video for the purchase of drones) and the perpetrators be exposed.

The images that are the result of these two projects cannot be further apart from each other - on the one hand, we have highly technical, to the naked eye completely vague satellite imagery, on the other vernacular snapshots of bomb holes, injured civilians, and dead, burnt bodies. Whereas the first can be believed only through trust in the interpretive apparatus (pointers, diagrams, close-ups, before-after images of the changing landscape), the second can be believed on the grounds of their vernacular aesthetics. Similar to the way we have discovered in forensic photography, both approaches follow the representational paradigm of what can constitute "a document" in contemporary legal ideology.

The impact of these two projects is still, after so many years, under question. The international community has been stirred to action, but to limited effect, since there is no political will to seriously act upon the results from these two projects - there are no immediate sanctions against the Khartoum regime (being blocked mostly by China and Russia, but silently also by the EU and USA). 
Even more, the culprit is not only North Sudan - it seems that even the South Sudanese political elites are profiting from the conflicts. It is of no surprise that from 2015 onwards the SSP ceased its activities. Its "founding fathers" created a new NGO - The Sentry:

"The Sentry is a team of policy analysts, regional experts, and financial forensic investigators that follows the money in order to create consequences for those funding and profiting from genocide or other mass atrocities in Africa, and to build leverage for peace."

Following the money, The Sentry found culpability on five continents of the earth: Europe, North America, Africa, Asia, and Australia. At the end, it must be admitted that the representational strategies employed in these two projects and their efforts to combat the atrocities in Sudan are simply no match for the political and corporate power unleashed on people in $21^{\text {st }}$ century. Consequently, it seems that representational strategies in general (art and documentary) and their theoretical analysis are even less a match for the global powers. And it is only on the grounds of such an insight that any socially engaged theory and practice can staggeringly move forward, especially so if the aim is not a grand global change but small-scale local one. It is then that the power of the camera to structure reality by its mere presence could be harnessed to its full (yet still limited) potential. It is on this power of photography (prophotographic) - to directly engage and change the events accruing - that maybe we should theoretically, if not even more practically, focus a bit more attention. On the photographic act, on the process of photographing itself. 


\section{Bibliography}

BATCHEN, G. (2004): Forget Me Not: Photography and Remembrance. New York, Amsterdam: Princeton Architectural Press, Van Gogh Museum.

BAZIN, A. ([1948] 2010): "Ontologija fotografske podobe", Fotografija, No. 43, 44, Membrana (ZSKZ), 50-53.

BENJAMIN, W. (2005): "Little History of Photography", in: Jennings, M. W., Eiland, H., and G. Smith, eds., Selected Writings, vol. 2, part 2, 1931-1934. Cambridge, Massachusetts, and London: The Belknap Press of Harvard University Press.

DASTON, L. and GALISON, P. (2007): Objectivity. New York: Zone Books.

EYES AND EARS OF GOD. Available at: http://www.tomokriznar. com/ang/index.php?li=novice [11.9.2013].

FLUSSER, V. (2010): K filozofiji fotografije. Ljubljana: Membrana (ZSKZ) in Društvo 2 koluta.

HUTCHINGS, P. J. (1997): "Modern Forensics: Photography and Other Suspects" Cardozo Studies in Law and Literature, Vol. 9, No. 2 (Autumn-Winter), 229-243.

MOZAYANI, A. and NOZIGLIA, C., eds. (2011): The Forensic Laboratory Handbook: Procedures and Practice. New York, Dordrecht, Heidelberg, London: Springer, Humana Press.

PINNEY, C. (2011): Photography and Anthropology. London: Reaktion Books Ltd.

PINNEY, C. and PETERSON, N. eds. (2003): Photography's Other Histories. Durham \& London: Duke University Press.

TAGG, J. (1993): The Burden Of Representation: Essays on Photographies and Histories. Minneapolis: University Of Minnesota Press. THE SATELLITE SENTINEL PROJECT. Available at: http://www. satsentinel.org/ [11.9.2013].

THE SENTRY. Available at: https://thesentry.org/ [28.10.2017]. 
VON BRAUCHITSCH, B. (2012): "Crime Scene Picture”, European Photography, Vol. 33, no. 91, issue 1, summer. 